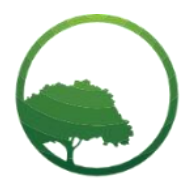

Research in Business \& Social Science

IJRBS VOL 10 NO 6 ISSN: 2147-4478

\title{
The effect of investment risks on stock return in the agricultural sector
}

\author{
(D) Ali Sadikin (a) (D) Fahmi Roy Dalimunthe ${ }^{(b)}$ \\ ${ }^{(a, b)}$ Departement of Management, Faculty of Economics and Business, University of Lambung Mangkurat, Banjarmasin, Indonesia
}

\author{
A R T I CLE INFO \\ Article history: \\ Received 17 August 2021 \\ Received in rev. form 12 Sep. 2021 \\ Accepted 14 Sept 2021 \\ Keywords: \\ Interest Rate Risk, Exchange Risk, \\ Liquidity Risk, Inflation Risk, Stock \\ Returns \\ JEL Classification \\ $\mathrm{O} 15$
}

\begin{abstract}
A B S T R A C T
This study purposes to determine the impact of risks of investment on stock returns of the agricultural sector in wetlands listed on the IDX for the period 2016-2019. This study uses secondary data while the analysis tool uses multiple linear regression (SPSS 21). The research population is 21 companies and the sample is 17 companies. The research sampling technique uses purposive sampling. The object of research is the agricultural sector which is listed on the Indonesia Stock Exchange for the period 2016 to 2019. This study also uses some classical assumptions. Testing the research hypothesis was done by t-test (partial test) and the coefficient of determination test. The results of the study are that 2 independent variables have a significant effect, namely interest rate risk (X1) in a positive direction and exchange risk in a negative direction, while liquidity risk and inflation risk have no significant effect with negative and positive directions on stock returns of the agricultural sector listed on the IDX for the period 2016-2019. The result of the research determination coefficient is $15.1 \%$.
\end{abstract}

(C) 2021 by the authors. Licensee SSBFNET, Istanbul, Turkey. This article is an open access article distributed under the terms and conditions of the Creative Commons Attribution (CC BY) license (http://creativecommons.org/licenses/by/4.0/).

\section{Introduction}

The role of the agricultural sector in the national economy is very important and strategic. This is mainly because the agricultural sector still provides employment for the majority of the population in rural areas and provides food for the population. Another role of the agricultural sector is to provide raw materials for industry and generate foreign exchange through non-oil exports. Even the agricultural sector can become a safety valve for the national economy in the face of the economic crisis that hit Indonesia in the last decade (MediaIndonesia, 2021). The agricultural sector is the savior sector of the national economy because its growth in the second quarter of 2020 Gross Domestic Product (GDP) is very high, in declining national GDP and other sectors (BPS.go.id, 2019).

Increasing the production capacity of agricultural sector products in Indonesia needs to be balanced with capital for production investment. Therefore, many companies in this sector seek capital in the capital market, by issuing securities such as new shares and bonds, known as IPOs (initial public offerings) to investors in the Indonesian capital market. the reasons for the agricultural sector as the object of research are because the agricultural sector requires large working capital in the form of large fixed assets and requires large working capital in its operational activities, therefore companies need to look for additional working capital both internally by the company and external funding of the company such as issuing new securities such as bonds. , stocks and other derivatives in the capital market.

According to (Tandelilin, 2010), one of the means to invest is through the capital market, because the capital market is a meeting between parties who have excess funds and those who need funds by trading securities such as stocks, bonds, mutual funds, and other derivatives so that there is a more efficient allocation of capital use, namely from the unemployed sector to the more productive sector.

The parties who carry out investment activities are called investors. Investors can generally be classified into two, namely individual investors (individual/retail investors) and institutional investors (institutional investors). Individual investors consist of individuals

* Corresponding author.ORCID: 0000-0003-3846-5447

(C) 2021 by the authors. Hosting by SSBFNET. Peer review under responsibility of Center for Strategic Studies in Business and Finance. https://doi.org/10.20525/ijrbs.v10i6.1328 
who carry out investment activities. While institutional investors usually consist of insurance companies, depository institutions (banks and savings and loan institutions), pension fund institutions, and investment companies.

Investment is a commitment to several funds or other resources carried out at this time, to obtain several benefits in the future. An investor buys several shares today in the hope of earning a profit on the share price or several dividends in the future, in return for the time and risk associated with the investment.

Besides return, investment is also known as the concept of risk. Risk is an important factor in investment decisions. Investment risk can be interpreted as the possibility of a difference between the actual return (actual return) and the expected return (Jones, 2010). Return and risk are important investment concepts, where risk and return are like two sides of a coin that are always sided by side, meaning that in investing, in addition to calculating the expected return, investors must also pay attention to the risks that must be borne. Therefore, investors must be smart in looking for investment alternatives that offer the highest level of return with a certain level of risk, or investments that offer a certain return at the lowest risk level, or in other words an investor who wants to maximize their utility level by choosing (portfolio) investment that has the highest rate of return at a certain level of risk.

According to (Tandelilin, 2010), several sources of risk can affect the magnitude of the risk of an investment. These sources are interest rate risk, market risk, inflation risk, business risk, financial risk, liquidity risk, exchange risk, and country risk. This is also in line with (Alwi, 2003), that the internal factors are price changes, new product withdrawals, funding, manager changes, mergers, factory expansion, labor strikes, and announcements of company financial statements, while external factors are economic conditions, turmoil domestic politics, changes in interest rates, inflation, foreign exchange rates and various economic regulations and deregulations issued by the government

Interest rate (BI rate) is a policy interest rate that reflects the monetary policy stance or stance set by Bank Indonesia and announced to the public. The BI rate (interest rate) is announced by the Board of Governors of Bank Indonesia at each monthly Board of Governors meeting and implemented in monetary operations conducted by Bank Indonesia through liquidity management of the money market to achieve monetary policy operational targets. Interest Rate (BI Rate) has a negative relationship with the return of securities such as stocks, if interest rates rise, investors or investors will move funds to banking products such as deposits, so that the price of securities and securities returns will fall. Vice versa. This study is in line with (Setiyaningsih, 2020) that interest rate risk has a significant negative effect on stock returns on the LQ 45 index, but this study also contradicts research conducted by (Khasanah, 2018), where interest rate risk factors do not affect returns. shares of the automotive and component sub-sector listed on the IDX for the period 2006-2016.

Exchange rate (exchange rate) can be said as a way of appreciating one currency to another. Changes in exchange rates are subject to differences in international interest rates. This change in the exchange rate (exchange rate) causes risks in international trade transactions. The use of exchange rates to facilitate international trade transactions. Exchange rate changes can increase the company's production costs and ultimately increase the price of final goods which in turn decreases the company's stock return. This study is in line (Saputri et al., 2020) (that exchange risk has a significantly negative effect on stock returns in the Agriculture and Mining sector listed on the IDX for the period 2009-2019. However, this study is not in line (Ramadhan Alfi Syahrin dan Ari Darmawan, 2018), where the exchange rate risk factor does not affect the stock returns of companies that go public on the IDX.

Liquidity is the company's ability to meet short-term finances by using its current assets. High liquidity can influence investors to invest in companies so that the demand for company shares will increase and then the price The liquidity risk used in this study is to see the extent to which a company can cover or pay its short-term capabilities with its current assets (Brigham, Eugene F. dan Houston, 2001). The liquidity ratio used is the current ratio, which is a ratio that calculates the company's ability to meet $u$ short-term (less than one year) with current assets. The higher the current ratio, the better the company's performance, the more investors will target its shares. This research is in line with (Nur Maulida Chasanah \& Aji Prasetyo, 2020) that liquidity risk has a significant positive effect on stock prices of property and real estate companies and research. This study is not in line (Ningsih et al., 2019) that liquidity risk does not significantly affect the negative direction of the agricultural industry for the 2014-2018 period.

Inflation is defined as a process of increasing prices prevailing in an economy. In this inflation, there is also inflation risk or purchasing power risk, which means the risk caused by an increase in prices in general, so that in real terms the nominal amount of money is reduced or smaller than before inflation. That inflation risk can have an inverse effect on stock returns. This study is in line (Ningsih et al., 2019) that inflation risk has a significant negative effect on the agricultural industry for the 2014-2018 period. This research is not in line (Sawitri, 2021) where the exchange rate risk factor does not affect stock returns of food and beverage companies that go public on the IDX for the 2010-2014 period.

The object of my research is the share of the agricultural sector in wetlands. Based on the growth in the value of agricultural exports from the table and the large contribution of the benefits of the agricultural sector to the Indonesian people, this is the target of investors in the capital market, because the agricultural sector in the wetlands provides very good prospects. promising for investors (investors), thus increasing the stock return of the sector because the stock price increases. From the theory and research results above, I am interested in researching the impact of risks of investment on stock returns in the agricultural sector in the wetlands for the $2016-$ 2019 period. 


\section{Literature Review}

\section{Understanding Investment}

According to (Halim, 2006), investment is the placement of a fund at this time with the hope of obtaining profits in the future.

\section{Investment Purpose}

Basically, the purpose of people investing is to 'make some money'. Everyone may agree with the statement of investment objectives. But the statement is too simple, so we need to find a more precise answer about the purpose of people investing.

Risk

According to (Van Horn, James C. dan Wachowic, John M., 2005), risk is the difference between the actual return and the expected return. In making investment decisions, investors actually do not know the rate of return because the expected return has not yet occurred, so it is not known exactly how much the value is. The uncertainty of the rate of return is related to risk. The greater the risk of a security, the higher the expected rate of return, or vice versa.

There are several sources of risk that can affect the amount of risk of an investment according to (Tandelilin, 2010), namely:

i. Interest rate risk. Changes in interest rates will affect the variability of the return of an investment.

ii. Market risk. Overall market fluctuations that affect the variability of the return of an investment are referred to as market risk.

iii. Inflation risk. Inflation risk is commonly referred to as purchasing power risk, if inflation increases it will reduce the purchasing power of the invested rupiah.

iv. Financial risk. This risk is related to the company's decision to use loans in financing its capital.

v. Liquidity risk. This risk is related to the speed with which a company's issued shares can be traded on the secondary market.

vi. Currency exchange rate risk (exchange rate). This risk is related to fluctuations in the value of the domestic currency against the currency of other countries and is often referred to as currency risk or exchange rate risk.

vii. Country risk or country risk. This risk is related to the condition of a country's political stability.

\section{Interest Rate Risk}

Changes in interest rates can affect the variability of the return of an investment. Changes in interest rates will affect stock prices inversely, ceteris paribus. That is, if interest rates increase, then stock prices will fall, ceteris paribus. Otherwise, if interest rates fall, stock prices rise. Or interest rate risk, namely the risk caused by changes in the interest rate on savings and loan interest rates. For example, the interest rate increases, the change will affect investment choices in stocks, bonds and deposits. High interest rates can cause the return obtained from low-risk investments (deposits) to be higher than the returns on high-risk investments (stocks), so investors will be more interested in placing their funds in the form of deposits rather than buying shares, which in turn costs capital (cost of investment). of capital) becomes high so that the value of the firm becomes low. So I can conclude that the relationship between interest rate risk and stock returns is inverse (negative).

\section{Exchange Risk}

The relationship between the exchange rate and stock returns is directly proportional, because it is an investor's appreciation. The stronger the rupiah exchange rate against the dollar, the greater the level of stock returns received by investors, because it is followed by a decrease in applicable interest rates, on the contrary, the weaker the rupiah exchange rate against the dollar, the lower the stock return received by investors, because it is followed by an increase in prevailing interest rates. (Tandelilin, 2010). So, the stronger the US dollar exchange rate or the weaker the rupiah exchange rate against the dollar, the company that has debt in dollars will find it difficult to pay it off, thereby reducing the company's profit, which in turn lowers the company's stock return. So, it can be said that the relationship is positive.

\section{Liquidity risk}

Liquidity refers to the speed and ease with which an asset can be converted into cash or cash. Liquidity has value, the more liquid the company is, the less likely it is that the company will experience financial difficulties (ie difficulty in paying debts or buying the necessary assets). (Brigham, Eugene F. dan Houston, 2001) state that liquid assets are assets that can be converted into cash quickly without reducing the price of the asset too much. The higher the liquidity of a company, the higher the return on the company's shares, because investors believe in the company's future prospects, so that the company's shares become the target of investors, become very liquid (easy to sell), and vice versa. So it can be said that the relationship between variable $\mathrm{X}$ and variable $\mathrm{Y}$ is positive. 


\section{Inflation Risk}

(Sukirno, 2002), defines inflation as a process of increasing prices prevailing in an economy. In this inflation there is also inflation risk or purchasing power risk, which means the risk caused by an increase in prices in general, so that in real terms the nominal amount of money is reduced or smaller than before inflation. Inflation can be measured using the consumer price index (Customer Price index).

\section{Return on Investment}

Return or return on investment is the main goal for investors as a reward or sacrifice of money or other economic resources from the investment. Returns can be in the form of realized returns that have occurred or expected returns that have not occurred but are expected to occur in the future.

The formula for the return of shares (Hartono, 2017), namely:

Return $=\frac{P_{t}-P_{t-1}+D_{t}}{P_{t-1}}$

Where :

$\mathrm{Pt}=$ Current share price $($ period $\mathrm{t})$

$\mathrm{Pt}-1=$ stock price last period $($ period $\mathrm{t}-1)$

$\mathrm{Dt}=$ dividends paid.

The conceptual framework in this study is as follows:

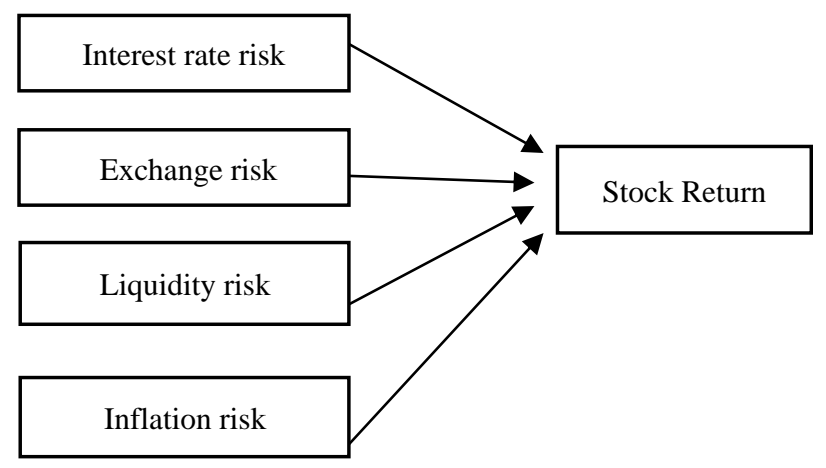

Figure 1: Conceptual Framework.

\section{Research and Methodology}

This study is causal. This causal research examines the effect of several independent variables on the dependent variable. The independent variables are interest rate risk, exchange risk, liquidity risk, and inflation risk, while the dependent variable is share return.

\section{The hypotheses used in this study are:}

The effect of interest rate risk on stock returns in the agricultural sector on wetlands listed on the IDX for the 2016-2019 period. According to the theory that interest rate risk harms stock returns. Based on previous research (Saputri et al., 2020) shows that interest rate risk has a significant effect on returns in the agricultural and mining sectors listed on the IDX, in a negative direction. Based on this research, the hypothesis is:

H1: Interest rate risk has a significant negative effect on stock returns in the agricultural sector on wetlands listed on the Indonesia Stock Exchange for the 2016-2019 period.

The effect of exchange rate risk on stock returns of the agricultural sector on wetlands listed on the IDX for the 2016-2019 period. Based on previous research (Ningsih et al., 2019) that exchange risk has a significant effect in a negative direction on stock returns in the Agriculture sector. Then the hypothesis is

H2: Exchange risk harms stock returns in the agricultural sector on wetlands listed on the IDX for the 2016-2019 period.

The effect of liquidity risk on stock returns in the agricultural sector in wetlands listed on the IDX for the 2016-2019 period. Based on previous research (Nur Maulida Chasanah \& Aji Prasetyo, 2020) that liquidity risk has a significant positive effect on the stock prices of property and real estate companies. Then the hypothesis is 
H3: Liquidity risk has a significant positive effect on stock returns of the agricultural sector on wetlands listed on the IDX for the 2016-2019 period.

The effect of Inflation risk on stock returns of the agricultural sector on wetlands listed on the IDX for the period 2016-2019. Based on previous research (Ningsih et al., 2019) that inflation risk has a significant effect in a negative direction on the agricultural industry for the 2014-2018 period. So, the hypothesis is

H4: Inflation risk has a significant negative effect on stock returns of the agricultural sector in wetlands listed on the IDX for the 2016-2019 period

This research was conducted on agricultural sector companies in wetlands that went public on the Indonesia Stock Exchange (IDX) in the 2016 period. -2019 at www.IDX.co.id, www. BI.go.id and www. BPS.go.id as well as at the ULM Stock Exchange Corner, the Banjarmasin Indonesia Stock Exchange, etc.

The population is a generalization area consisting of objects or subjects that have qualities and characteristics (Sugiyono, 1999). In this study, the population is all companies that enter the agricultural sector listed on the Indonesia Stock Exchange (IDX) with a population of 21 companies. The sample used is 17 companies in the wetland agriculture sector. The method used in sampling is using the purposive sampling method, namely the method of selecting research samples with certain criteria from the researcher.

The Source of data used in this study is secondary data. Secondary data is a source of research data that already exists and is deliberately collected by researchers for research purposes, such as www.Idx.go.id, www.BI.go.id, www.BPS.go.id, corner of BEI ULM and BEI Branch Banjarmasin.

The dependent variable in this study is the stock return of agricultural sector companies for the period 2016 to 2019 namely the current stock price minus the previous stock price divided by the previous stock price. The independent variable is the interest rate risk used as the reference interest rate with the name BI-7 Day Reverse Repo Rate (BI7DRR). Exchange Risk In this study, the exchange rate of the rupiah against the US dollar, the figure used is the middle rate between the selling rate and the buying rate of the rupiah against the US dollar set by Bank Indonesia at a certain time. The liquidity risk used in this study is the ratio of total current assets to total current liabilities. Inflation risk is using the consumer price index (Customer Price index). The use of the multiple regression statistical model above must meet the classical assumptions with the normality test of Multicollinearity, heteroscedasticity, and autocorrelation.

To test the relationship between research variables, using multiple regression analysis (SPSS 21).

$$
Y=\beta_{0}+\beta_{1} X_{1}+\beta_{2} X_{2}+\beta_{3} X_{3}+\beta_{4} X_{4}+e
$$

Where:

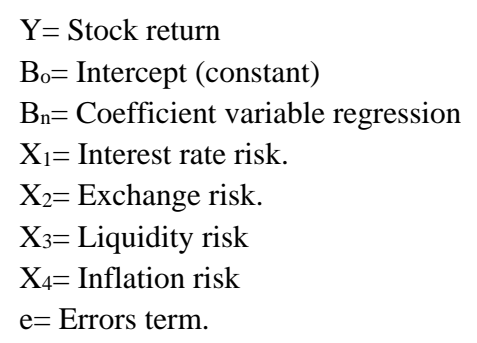

Performing the T-Test is used to test the hypothesis of the effect of the independent variable ( $\mathrm{X}_{\mathrm{i}}$ partially) on the dependent variable (Y) and Calculating the Coefficient of Multiple Determination $\left(\mathrm{R}^{2}\right)$ to measure the proportion or percentage of the number of variations (changes) of the independent variable $\left(\mathrm{X}_{1}\right)$., $\mathrm{X}_{2}$ and $\left.\mathrm{X}_{3}\right)$ to the dependent variable $(\mathrm{Y})$.

\section{Results and Discussion}

A classical assumption test is needed so that the data to be analyzed using multiple regression analysis formed can meet the BLUE equation (Best Linear Unbiased Estimator), the assumptions are as follows:

Normal data can be seen through a histogram graph plot or performed using the test Kolmogorov-Smirnov test with a significance value of more than 0.05 . 
Table 1: Normality Test Results

\begin{tabular}{lll}
\hline & & $\begin{array}{l}\text { Unstandardized } \\
\text { Residual }\end{array}$ \\
\hline $\mathrm{N}$ & Mean & 64 \\
Normal & Std. Dev & .00000 \\
Parameters & Absolute & .26169696 \\
Most Extreme & .109 \\
Differences & Positive & .109 \\
& Negative & -.082 \\
Test & & .109 \\
Asymp Statistic. Sig (2-tailed) & .055
\end{tabular}

a. Test distribution is Normal; b. Calculated from data; c. Lilliefors Significance Correction.

Table 1 shows that the Kolmogorov-Smirnov value for residual data in this study is 0.055 greater than 0.05 . Based on the results of this test, it can be concluded that the research data residues are normally distributed.

The multicollinearity test aims to see whether the regression model found a correlation between the independent (independent) variables. To find out whether multicollinearity symptoms occur or not, it can be seen from the Tolerance and VIF values contained in the table below

Table 2: Multicollinearity Test Results

\section{Coefficients}

\begin{tabular}{lll}
\hline Model & Collinearity Statistics & \\
\cline { 2 - 3 } & Tolerance & VIF \\
\hline 1 (Constant) & & 8.555 \\
Ln Risiko Suku Bunga & .177 & 7.353 \\
Ln Risiko Kurs & .136 & 1.011 \\
Ln Risiko Likuiditas & .989 & 1.545 \\
Ln Risiko Inflasi & .647 & \\
\end{tabular}

The regression model is declared free from multicollinearity if the Tolerance value is greater than 0.10 and the VIF value is less than 10. Table 2 shows that all variables are free from multicollinearity symptoms because they have a Tolerance value of more than 0.10 and a VIF value of less than 10 .

Test heteroskedasticity was performed to determine whether in a regression model occurred inequality residual variance from one observation to another observation. To find out whether or not heteroscedasticity occurs between independent variables, see the following figure:

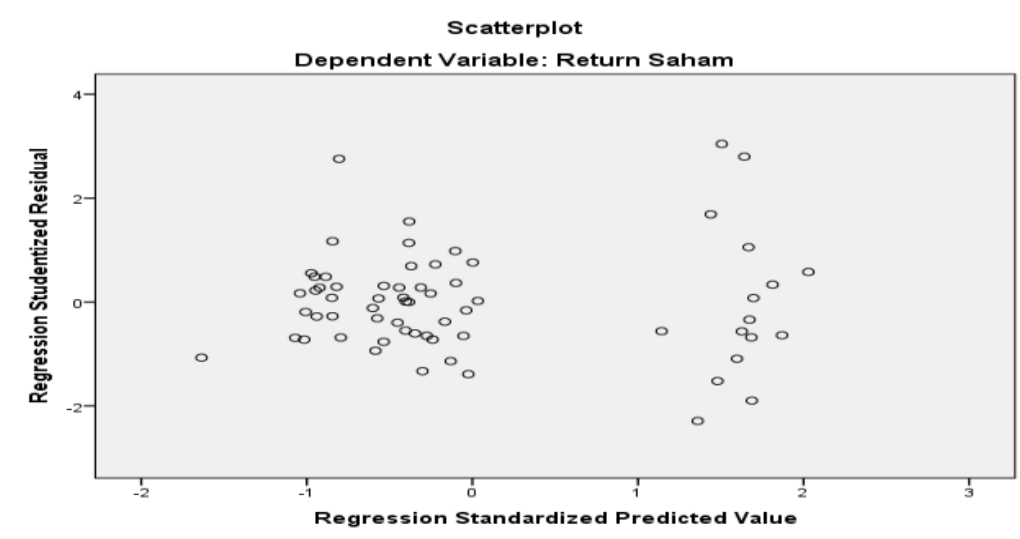

Figure 1: Heteroscedasticity Test Results 
Based on the picture above, it can be seen that the data (dots) spread widely above and below the zero lines, not gathered in one place, and not make a certain pattern so that it can be concluded that there is no heteroscedasticity problem.

The autocorrelation test was conducted to see whether in the linear regression model there was a correlation between the confounding error in period $t$ and the confounding error in period $t-1$ (previous). The dependent and independent variable data used is the data after the transformation in the previous tests. The test used to see the symptoms of autocorrelation is the Durbin-Watson (DW) test, the results can be seen in Table 3 below:

Table 3: Autocorrelation Test

Model summary

\begin{tabular}{llllll}
\hline Model & $\mathbf{R}$ & $\mathbf{R}^{\mathbf{2}}$ & $\begin{array}{l}\text { Adj } \\
\mathbf{R}^{\mathbf{2}}\end{array}$ & $\begin{array}{l}\text { Std. The error } \\
\text { of the Estimate }\end{array}$ & Durbin-Watson \\
\hline $\mathbf{1}$ & .453 & .205 & .151 & .2704 & 2.47
\end{tabular}

a. Predictors: (Constant), Inflation, Liquidity, Exchange, Interest Rate; b. Dependent Variable: Stock ReturnBased on the results in the table, the DW value obtained is 2.472 while the DU value at $n=64$ and $\mathrm{k}=4$ is 1.7303 so $4-\mathrm{DU}=2.2697$, DW value is outside the range DU < DW < 4-DU. The table below shows the results of the multiple linear regression test of this study:

Table 4: Results of the Multiple Linear Analysis Test

\section{Coefficients $^{\text {a }}$}

\begin{tabular}{llll}
\hline Model & $\begin{array}{l}\text { Unstandardized } \\
\text { Coefficient }\end{array}$ & t Statistic & Sig \\
\hline Constant & 101.624 & 3.083 & .003 \\
Ln Rs SB & 1.764 & 2.222 & .030 \\
Ln Rs Krs & -10.082 & -3.198 & .002 \\
Ln Rs Lk & -.028 & -.941 & .350 \\
Ln Rs Inf & .060 & .144 & .886 \\
\end{tabular}

a. Dependent Variable: Return Saham

Then the multiple regression equation is as follows:

$$
Y=101.624+1,764 X 1-10,082 \text { X2 - 0.028 Ln X3 + 0.060 X4 }
$$

Based on the results of the multiple linear regression test from table 4 above, the following model equations can be analyzed:

i. Constants with a value of 101,624 indicate that if the independent variable is considered constant, then the stock return is 101,624

ii. The regression coefficient for interest rate risk is 1,764 which states that each additional interest rate risk of one unit will have an impact on the increase in stock returns of 1,764

iii. The regression coefficient for Exchange risk is -10,082 states that each additional unit of exchange risk will have an impact on decreasing stock returns by 10,082

iv. Liquidity risk regression coefficient of -0.028 states that every additional unit of liquidity risk will have an impact on decreasing stock returns of -0.028

v. The inflation regression coefficient of 0.060 states that every time there is an increase in inflation risk of one unit, it will have an impact on an increase in stock returns of 0.060 .

The t-test (partial test) of the research hypothesis was conducted to test the effect of the independent variables on the dependent variable, namely the effect of interest rate risk (X1), exchange rate risk (X2), liquidity risk (X3), and inflation risk (X4) on stock returns. $(\mathrm{Y})$. In conducting the test to determine the effect of the independent variable on the dependent variable with a significance level $(\alpha)$ of $=5 \%$. If the P-value $<0.05$, the independent variable has a significant effect on the dependent variable. 
Table 5: Results of t-test

\begin{tabular}{llll}
\hline Model & $\begin{array}{l}\text { Unstandardized } \\
\text { Coefficient }\end{array}$ & t Statistic & Sig \\
\hline Constant & 101.624 & 3.083 & .003 \\
Ln Rs SB & 1.764 & 2.222 & .030 \\
Ln Rs Krs & -10.082 & -3.198 & .002 \\
Ln Rs Lk & -.028 & -.941 & .350 \\
Ln Rs Inf & .060 & .144 & .886 \\
\hline
\end{tabular}

Adj $R^{2}=0,151$

Based on the table above, the level of influence of the independent variables on the dependent variable can be described as follows: effect

Hypothesis 1: Interest rate risk has a significant negative against stock returns of the agricultural sector in wetlands listed on the IDX for the 2016-2019 period.

The results of testing interest rate risk $(\mathrm{X} 1)$ on stock returns $(\mathrm{Y})$ in Table 5 show that the risk interest rate $(\mathrm{X} 1)$ has a regression coefficient value of 1.764 and has a significance value of 0.030 which is smaller than the value of 0.05 . So it can be concluded that the risk interest rate $(\mathrm{X} 1)$ has a significant positive effect on the stock return variable (Y). This result is following the hypothesis that $\mathrm{H} 0$ is rejected and $\mathrm{H} 1$ is accepted.

Hypothesis 2: Exchange risk has a significant negative effect on stock returns in the agricultural sector in wetlands listed on the IDX for the 2016-2019 period.

The results of oftest exchange risk (X2) on stock returns (Y) in Table 5 show that the exchange risk rate has a regression coefficient value of $-10,082$ and has a significance value of 0.020 which is smaller than the value of 0.05 . So it can be concluded that the exchange rate risk has a significant negative effect on stock returns (Y). This result is following the hypothesis that $\mathrm{H} 0$ is rejected and $\mathrm{H} 1$ is accepted.

Hypothesis 3: Liquidity risk has a significant positive effect on stock returns of the agricultural sector in wetlands listed on the IDX for the 2016-2019 period.

The results of testing the risk Liquidity (X3) on stock returns (Y) in Table 5 that the risk Liquidity (X3) has a regression coefficient value of -0.028 and has a significance value of 0.350 which is greater than the value of 0.05 . So it can be concluded that liquidity risk has a negative direction and has no significant effect on the stock return variable (Y). Then the hypothesis $\mathrm{H} 0$ is accepted and $\mathrm{H} 1$ is rejected.

Hypothesis 4: Inflation risk has a significant negative effect on agricultural stock returns in wetlands listed on the IDX for the 20162019 period.

The results of testing the risk inflation $(\mathrm{X} 4)$ on stock returns (Y) in Table 5 show that the inflation risk (X4) has a regression coefficient value of 0.060 and has a significance value of 0.886 which is greater than the value of 0.05 . So it can be concluded that the inflation risk has a positive direction and has no significant effect on the stock return variable (Y). Then the hypothesis $\mathrm{H} 0$ is accepted and $\mathrm{H} 1$ is rejected. Coefficient determination or adjusted $\mathrm{R}^{2}$ is a form of testing to inform how much of the research model explains variations in the percentage of dependent variables. The determination value is in the range of zero to one (1).

Based on Table 5 above can be seen the value of Adjusted $\mathrm{R}^{2}$ of 0151 , or $15.1 \%$ means that the interest rate risk, foreign exchange risk, liquidity risk, and the risk of inflation in explaining variable stock return agricultural sector amounted to $15.1 \%$ and the remaining $84.9 \%$ affected by other risks. While this research discusses that risk interest rate(X1) has a positive direction and a significant influence on the stock return variable (Y). Then the hypothesis H0 is rejected and H1 is accepted. Interest rate risk (X1) greatly affects the return of securities such as stock returns $(\mathrm{Y})$ of agricultural sector companies in wetlands, with a positive direction of research results (unidirectional). This means that before investing their funds (investing) in the capital market, they must look at the interest rate risk factor (BI Rate) because these risk factors can affect the expected yield of investment securities for investors.

That the risk exchange rate $(\mathrm{X} 2)$ has a negative direction and has a significant effect on stock returns (Y). then the hypothesis H0 is rejected and $\mathrm{H} 1$ is accepted. The risk variable Exchange rate (X2) greatly affects the return of securities such as stock returns (Y) of companies in the agricultural sector in wetlands, with the direction of the research results being negative (opposite). This means that investors must also be careful in investing in securities (stocks) because changes in the dollar exchange rate against the rupiah can affect the yield of a security, such as stocks. After all, the exchange rate risk factor can directly affect the price of fertilizers and plant medicinal prices imported abroad. So, that the production cost becomes expensive which in the end affects the profit of the agricultural company, and the stock return falls.

That liquidity risk (X3) has a negative direction and has no significant effect on stock returns (Y). Then the hypothesis H0 is accepted and $\mathrm{H} 1$ is rejected. Liquidity risk variable (X3) greatly affects the return of securities such as stock returns (Y) of agricultural sector 
companies in wetlands, with the direction of the results of the study being negative (opposite). Liquidity risk (X3) which is proxied by the ratio of total current assets to total current liabilities, the higher this current ratio, it can be said that the better because the risk of bankruptcy is getting smaller, this is considered a good signal for investors to invest in the capital market, but the results have no effect, it can be explained that investors in investing do not only look at this ratio but also look at other factors such as profitability, etc. the profit of agricultural companies continues to increase from year to year so that shares in the agricultural sector still have good prospects, this can be seen from the increasing volume of exports of agricultural and plantation products every year.

That the variable risk inflation (X4) has a positive direction and has no significant effect on stock returns (Y). Then the hypothesis $\mathrm{H} 0$ is accepted and $\mathrm{H} 1$ is rejected. We know that inflation risk can affect security returns in a negative direction. However, the results of this study were positive. This means that although inflation risk is important for investors, investors must also understand the factors that influence stock returns of an agricultural company such as profit growth rates, sales levels, factors for developing agricultural and plantation commodity prices, etc.

\section{Conclusions}

That the interest risk rate has a positive direction and significant effect on stock return variables in the agricultural land sector listed on the Indonesia Stock Exchange for the 2016-2019 period. This result is following the hypothesis that H0 is rejected and H1 is accepted, as well as exchange risk has a negative direction and has a significant effect on stock returns in the agricultural land sector listed on the Indonesia Stock Exchange for the 2016-2019 period. This result is following the hypothesis that H0 is rejected and H1 is accepted. Meanwhile, liquidity risk and inflation risk have no positive or negative effect on the return of the agricultural land sector listed on the Indonesia Stock Exchange for the 2016-2019 period. Then the hypothesis H0 is accepted and H1 is rejected.

\section{Acknowledgement}

Thanks to the University of Lambung Mangkurat for the compulsory research lecturer program (PDWM) Supported DIPA the University Lambung Mangkurat Fiscal Year 2021 Number: SP DIPA- 023.17.2.677518/2021 November 23, 2020. Ministry of Education and Culture Following the Decree of the Chancellor of Lambung Mangkurat University Number: 679/UN8/PG/2021 March 22, 2021

\section{References}

Alwi, I. Z. (2003). Pasar modal: teori dan aplikasi (Pertama). Penerbit Yayasan Pancur Siwah.

BPS.go.id. (2019). Ekonomi Indonesia 2018. https://www.bps.go.id/pressrelease/2019/02/06/1619/ekonomi-indonesia-2018tumbuh-5-17-persen.html

Brigham, Eugene F. dan Houston, J. F. (2001). Dasar-Dasar Manajemen Keuangan (Edisi ke-9). Penerbit Erlangga.

Halim, A. (2006). Analisis Investasi (Edisi pert). Penerbit Salemba Empat.

Hartono, J. (2017). Teori Portopolio dan Analisis Investasi (BPFE (ed.); Edisi ke s).

Khasanah, Y. N. (2018). Pengaruh risiko inflasi, risiko suku bunga, risiko kurs valuta asing dan leverage terhadap return saham sektor otomotif dan komponen yg terdaftar di BEI periode 2006-2016). Universitas Brawijaya.

MediaIndonesia. (2021). WWW.MediaIndonesia.com.

Ramadhan Alfi Syahrin dan Ari Darmawan. (2018). Pengaruh risiko inflasi, risiko suku bunga, risiko valuta asing, risiko pasar terhadap return saham. Jurnal Administrasi Bisnis (JAB), Vol 61 no.

Saputri, D., Tahmat, Garnia, E., \& Rizal, D. (2020). Pengaruh Inflasi, Suku Bunga, Nilai Tukar dan Produk Domestik Bruto Terhadap Return Saham Sektor Pertanian dan Sektor Pertambangan Periode 2009 - 2019. JEMPER (Jurnal Ekonomi Manajemen Perbankan), 2(2), 112. https://doi.org/10.32897/jemper.v2i2.418

Sawitri, E. P. dan A. P. (2021). Pengaruh inflasi, suku bunga dan nilai tukar rupiah terhadap return saham. Jurnal Neraca, vol 5 no I(Juni 2021), 41-47. https://doi.org/10.31851/neraca.v5i1.5630

Setiyaningsih, D. R. (2020). Indeks Harga Saham Gabungan Terhadap Return Saham Pada Indeks Lq 45 Di Bursa Efek Indonesia Tahun 2017-2019.

Sugiyono. (1999). Metode Penelitian Bisnis (Pertama). Alfabeta.

Sukirno, S. (2002). Teori Mikro Ekonomi (cetakan ke). Rajawali Press.

Tandelilin, E. (2010). Portofolio Investasi dan Pasar Modal (Edisi Pert). Kanisius.

Van Horn, James C. dan Wachowic, John M., J. (2005). Dasar-dasar Manajemen Keuangan (Edisi ke 1). Penerbit Erlangga.

Publisher's Note: SSBFNET stays neutral with regard to jurisdictional claims in published maps and institutional affiliations. (c) (1)

(C) 2021 by the authors. Licensee SSBFNET, Istanbul, Turkey. This article is an open access article distributed under the terms and conditions of the Creative Commons Attribution (CC BY) license (http://creativecommons.org/licenses/by/4.0/).

International Journal of Research in Business and Social Science (2147-4478) by SSBFNET is licensed under a Creative Commons Attribution 4.0 International License. 